•综述・

\title{
中国农业生物多样性保护进展概述
}

郑晓明, 杨庆文*

中国农业科学院作物科学研究所, 北京 100081

摘要: 农业生物多样性是农业安全生产的基础条件和农业可持续发展的战略资源。中国自20世纪50年代就开始重视农业生物 多样性的保护, 建立了较为完善的法律法规等保障体系, 并在农业生态系统、物种和遗传多样性 3 个层面采取了一系列保护措 施, 基本形成了异位保存和原生境保护相互补充的保护体系, 取得了显著的保护成效。本文概述了中国近70年来农业生物多 样性保护在法律法规和保护机制、保护规划、保护体系和能力建设方面取得的进展，指出我国农业生物多样性保护面临着未 与国际国内发展战略相适应、保护体系不完整、保护能力不足等问题, 并提出完善我国农业生物多样性保护体系、促进农业 生态系统服务功能系统化、加快农业生物多样性主流化进程以及加强能力建设等相关建议。

关键词: 农业生物多样性; 法律法规; 可持续发展; 生态系统服务; 能力建设

郑晓明, 杨庆文 (2021) 中国农业生物多样性保护进展概述. 生物多样性, 29, 167-176. doi: 10.17520/biods.2020077.

Zheng XM, Yang QW (2021) Progress of agricultural biodiversity conservation in China. Biodiversity Science, 29, 167-176. doi: 10.17520/biods.2020077.

\section{Progress of agricultural biodiversity conservation in China}

Xiaoming Zheng, Qingwen Yang*

Institute of Crop Sciences, Chinese Academy of Agricultural Sciences, Beijing 100081

\begin{abstract}
Aim: Agricultural biodiversity has a significant influence on agricultural production and plays an important role in sustainable development. The Chinese government has emphasized agricultural biodiversity conservation since the early 1950s and achieved many progresses. Here, we summarize China's main progress toward establishing a supporting system of legislation, policies, research, and capacity building in agricultural biodiversity conservation over the past 70 years, and provide suggestions for the conservation of agricultural biodiversity in the future.

Progresses: China has formulated laws and regulations related to agricultural biodiversity, established management mechanisms, mapped out related programs, and implemented research and capacity building projects. It has also taken conservation actions at the levels of ecosystems, species, and genes. More recently, China established a primary conservation system with both in-situ and ex-situ approaches. We also highlight important gaps in the areas of agricultural biodiversity conservation compared to international and national development strategies, describe the requirements associated with enhancing the conservation system in China, and underscore the need to build capacity.

Prospects: We propose that agricultural biodiversity conservation in China should align with international regulations, such as the Nagoya Protocol and the International Treaty on Plant Genetic Resources for Food and Agriculture (ITPGRFA), promote ecosystem services, create a streamlined process across government sectors, and increase public capacity.
\end{abstract}

Key words: agricultural biodiversity; legislation; sustainable development; ecosystem services; capacity building

农业生物多样性包括所有栽培或养殖的动植 物及其野生近缘种以及与之相互作用的授粉者、共
生成分、害虫、寄生植物、肉食动物和竞争者，从 品种(种内)、半栽培和采集管理种(物种层次), 到具

收稿日期: 2020-03-05; 接受日期: 2020-07-16

基金项目：农业部专项财政项目(2130135)、中国农业科学院科技创新工程和国家自然科学基金(31970237; 31670211)

* 通讯作者 Author for correspondence. E-mail: yangqingwen@caas.cn 
有多物种的农业生态系统以及由此而形成的农地 景观和相关技术、文化、政策等。农业生物多样性 是人类起源 300 万年以来的文明成就和遗产, 随着 人类的发展而丰富或减少(郭辉军等, 2000)。全球约 40\%的土地面积被用于农业生产, 农业生物多样性 会直接影响农业生产, 最终影响全球粮食安全和生 态安全(李波, 1999)。农业生物多样性的减少会使人 类适应环境的能力下降, 为畜禽及农作物品种改良 提供的遗传资源减少, 因此, 农业生物多样性是与 粮食和农业密切相关并对农业生态系统起支持作 用的战略资源。据初步调查统计, 我国有9,631个粮 食和农业植物物种, 其中, 栽培和野生近缘植物 3,269 种, 采集与放牧植物 4,204种, 田间杂草与有 毒植物2,218种; 家畜、家禽品种类型590种; 水产类 物种 17,447 种; 食用菌类 966 个分类单元, 还有大量 栽培作物、养殖动物和微生物的野生近缘物种, 许 多物种及其生境类型都具特有性(刘旭等, 2008)。许 多具有重要意义的物种以农区为主要栖息地, 由于 土地集约化利用和环境污染、外来入侵物种的影响 以及气候变化等, 造成农业生物多样性急剧下降, 栽培(或养殖)品种数量剧减, 野生近缘种居群大量 消失或分布面积严重萎缩。据估计, 在过去的一个 世纪里, 世界农业生物多样性损失了75\% (FAO, 2010)。因此, 加强农业生物多样性的保护具有十分 重要的意义(闻大中, 1995; 章家恩, 1999; 薛达元和 张渊媛, 2019)。为了更好地保护我国的农业生物多 样性, 有必要系统总结过去的保护经验, 梳理存在 的问题, 从而提出未来农业生物多样性保护的措施 和建议。

农业生物多样性包括农业生态系统、物种、品 种或地方品种以及管理系统4个层次(Long et al, 2003)。本文所说的遗传多样性既包括栽培物种内不 同品种间的遗传变异, 也包括野生近缘种居群间和 居群内个体间的遗传变异; 物种多样性主要以栽培 或养殖的物种及其野生近缘种为主; 农业生态系统 多样性则仅仅考虑与农业生产有关的生态系统, 例 如农田生态系统、农牧结合生态系统、淡水养殖生 态系统等。

\section{1 中国农业生物多样性保护已采取的措施}

\section{1 完善法律法规和保护机制}

农业生物多样性作为战略性资源, 国家高度重
视其保护与利用的立法工作, 颁布了《中华人民共 和国环境保护法》 《中华人民共和国畜牧法》 《中 华人民共和国森林法》 《中华人民共和国草原法》

《中华人民共和国种子法》 《中华人民共和国渔业 法》 《中华人民共和国野生动物保护法》 《中华人 民共和国野生植物保护条例》 《农作物种质资源管 理办法》《中华人民共和国自然保护区条例》和《中 华人民共和国水产资源繁殖保护条例》等国家级法 律法规, 省部级立法也在逐步加强(史学瀛和郭融, 2011; 史瑞芳，2013)。农业农村部成立了农业野生 植物管理办公室、外来物种管理办公室等管理机构, 并由农业环境与资源保护总站负责具体业务工作。 省级农业农村厅(委、局)均下设农业环境管理机构, 大部分地(市、州)和县级农业农村局也设有环保站 或专人从事农业生物多样性保护工作。中国农业生 态保护协会等民间机构、农业院校和研究所共同组 成了我国农业生物多样性保护网络(张风春等, 2015), 基本形成了从中央到地方的农业生物多样 性保护机制。

\section{2 发布实施一系列农业生物多样性保护规划}

近20年来, 我国政府发布并实施了《全国主体 功能区规划》 《中国生物多样性保护战略与行动计 划》《全国生物物种资源保护与利用规划纲要》《全 国生态环境建设规划》《全国草原保护建设利用总 体规划》 《中国水生生物资源养护行动纲要》《全 国海洋功能区划(2011-2020年)》《全国畜禽遗传资 源保护与利用规划》和《全国农作物种质资源保护 与利用中长期发展规划(2015-2030年)》等一系列规 划, 这些规划从宏观到具体保护目标, 使生物多样 性全方位纳入当地经济社会发展规划中(薛达元和 张渊媛, 2019; 杨锐等, 2019)。

\section{3 初步建立农业生物多样性保护体系}

目前已建立了以自然保护区、保护小区、湿地 公园、水产种质资源保护区、农业野生植物原生境 保护点等原生境保护以及种质库和种质圃等异位 保存相结合的多层次农业生物多样性保护体系(杨 庆文等, 2003; 史学瀛和郭融, 2011)。实施重点保护 野生动植物利用管理制度、基本草原保护制度、草 畜平衡制度、禁牧休牧制度、渔业捕捞许可管理制 度、禁渔期和禁渔区制度等资源利用管理制度。完 善外来入侵物种防控的体制机制, 开展外来入侵物 种集中灭除行动, 既保护了农业生态系统的完整性, 
又防止了外来入侵物种对物种栖息地的侵蚀。建立 农业转基因生物安全评价制度和实现转基因技术 研发与应用的全过程管理, 为避免转基因品种对野 生近缘种的遗传侵蚀或演变为恶性物种奠定了坚 实的基础 (杨庆文等, 2005; 薛达元和张渊媛, 2019)。

\section{4 开展农业生物多样性保护能力建设}

各级政府采取多项措施、全方位宣传和广泛培 训, 鼓励全民参与保护, 将生物多样性保护相关知 识纳入中小学教育课程, 并在全国普通高校开展生 物多样性相关学科教育。利用各种宣传手段, 在保 护区和周边地区宣传保护区建立的意义和被保护 物种的重要性, 宣传有关法规, 提高当地居民和社 区的生态环境保护意识, 并使之成为日常生活中的 自觉行为(廖建基等, 2019)。与有 关国家和国际组织 开展与生物多样性保护有关的合作研究、互访、考 察和交流, 通过加入《保护世界文化和自然遗产公 约》和《保护非物质文化遗产公约》以及积极参与 《生物多样性公约》和《粮食和农业植物遗传资源 国际条约》谈判, 实施全球环境基金农业生物多样 性保护领域的项目等, 加强了农业生物多样性保护 的能力(张小勇和杨庆文, 2019)。

\section{2 中国农业生物多样性保护取得的成就}

\section{1 农业生态系统多样性保护}

农业生态系统与自然生态系统不同, 它与农业 生产和农村发展紧密相关, 因此, 农业生态系统保 护也不可能像自然生态系统保护那样大量建立自 然保护区, 而是将农业生态系统保护纳入生产体系 中, 通过改善农业生态系统以促进生产。我国农业 生态系统保护的全面实施以2000年农业部印发的 《全国生态农业示范县建设管理办法》为标志, 通 过农田生态工程、无公害农产品基地建设、猪-沼菜(果、鱼)种养结合、农田稻虾(鱼、蟹)共养、作物 轮作等生态模式的发展, 在改良农业生态系统的同 时提高生产能力(许仙菊等, 2016; 张立成等, 2017; 谢利芬等, 2018; 周建雄, 2018)。此后, 农田环境治 理、外来物种防控、生态沟渠建设、秸秆还田、免 耕休耕、禁渔休渔、禁牧轮牧和草畜平衡等众多举 措都体现了对农业生态系统保护的重视。特别是近 年来开展的生态文明建设、生态农业示范区(园)、 休闲农业、新农村建设和最美乡村建设等都极大地
促进了农业生态系统的改良和优化(王克磊等, 2017; 黄璜等, 2019; 蒋倩文等, 2019)。我国还出台了农业 景观生物多样性保护政策, 如鼓励立体种植、间套 作、野生动物廊道建设和防护林建设(丁陆涁等, 2019)。

生态农业示范点建设强调在保护生态系统的 前提下发展农业生产, 注重保护和建设并重, 控制 水土流失, 实行病虫害综合防治, 控制化学污染, 充分利用农家肥和种植绿肥作物, 建设生态沟渠, 同时进行产业结构调整。目前全国各地已有2,000 多个试点, 并正在迅速普及(彭春良等, 2020; 文志 等, 2019)。2017年农业部提出了控制农业用水、减 少农药化肥施用量和畜禽粪污、农膜、农作物秥秆 基本得到资源化、综合循环再利用和无害化处理的 “一控、两减、三基本”农业污染治理目标, 在通过 减少农业化肥的使用以减轻农业污染的同时, 增加 农业生态系统中动植物和微生物的多样性, 并通过 资源化利用, 以生态系统的方法解决畜禽粪便、秸 秆、地膜等对环境的污染和破坏。

农业文化遗产保护是农业生物多样性保护的 一个重要部分。农业文化遗产地的农业生物多样性 极为丰富, 传统品种保存于传统的农业生态系统中, 这些农业生态系统仍然是当地农民生计策略和传 统文化传承的重要载体。通过农民的农事活动和管 理, 保护遗传资源在农业生态系统中随着自然、社 会和经济的变化而不断适应和进化, 使其多样性得 以不断更新和丰富(张丹等, 2016)。在我国农业文化 遗产动态保护中已取得 3 个方面的成绩, 即有机农 业、生态旅游和生态补偿, 并试图通过这些措施来 增加农业文化遗产地的保护资金来源, 形成农业文 化遗产长期自我维持的机制(闵庆文等, 2007)。农业 文化遗产大多存在于落后、偏远、自然条件比较差 的地区, 这些农业系统很好地适应了当地特殊的自 然环境, 规模小而分散, 因地制宜地通过动态保护 和适应性管理, 建立了农业文化遗产长期自我维持 的机制。

\section{2 物种和遗传多样性保护}

农业物种多样性保护往往与遗传多样性保护 互为一体, 在注重遗传多样性保护的同时也保护了 物种多样性。我国大多数农业生物物种和遗传多样 性保护主要有异位保存和原生境保护两种方式。 


\subsection{1 异位保存}

异位保存是农业生物多样性保护的主要方式, 并在多个领域取得了较大进展。我国政府自20世纪 50 年代起就非常重视农作物种质资源的收集和异 位保存工作。1956-1957年, 当时的国家科委、农牧 渔业部组织了全国农作物种质资源征集活动, 共征 集粮食、油料、蔬菜、果树、牧草、绿肥、其他经 济作物等各类作物种质资源 20 余万份, 分别异位保 存在相关科研机构 (董玉琛和曹永生, 2003); 1978-1982年, 农牧渔业部又开展了全国性作物种 质资源的补充征集, 并进行了野生稻(Oryza rufipogon)、野生大豆(Glycine soja) 和野生茶 (Camellia sinensis)等多项专业性作物种质资源考察 和收集, 共补充征集和收集各类作物及其近缘野生 植物资源11万份(董玉琛和曹永生, 2003); 在“六五” 至“九五”计划期间的国家科技攻关项目中，科技部 组织了 “西藏作物种质资源考察” “海南岛作物种质 资源考察” “神农架及三峡地区作物种质资源考察” “川陕黔桂作物种质资源考察” “三峡库区作物种质 资源考察” 和“京九铁路沿线作物种质资源考察” 等 专项考察活动, 收集各类作物种质资源 4 万余份(郑 殿升和郝素琴, 1990); 财政部和农业部2001年启动 的 “作物种质资源保护专项” 和2015年启动的“第三 次全国农作物种质资源普查与收集行动”等进一步 加强了我国作物种质资源的收集和异位保存工作 (何娟娟和刘根泉, 2016)。

至2019年底, 我国已经完成1座长期库、1座复 份库、13座中期库、 48 个国家种质圃(含 2 个试管苗 库)的国家级异位保存体系建设, 已保存340种作物 达50万份的种质资源, 位居世界第二(卢新雄等, 2019)。中国科学院在云南建立了西南地区野生生物 种质资源库, 近期保存数量达到 6,450种66,500份 (株), 其中包括重复保存的种类、复份、菌株和细胞 株或细胞系(李德铢和娄治平, 2006)。此外, 我国还 建立了药用植物种质资源离体保护技术体系, 收集 药用植物离体种质近3万份, 涉及3,599个物种; 建 立了1座国家药用植物种质资源库, 是全世界收集 和保存药用植物种质资源最多的专业种质库, 并创 建了药用植物种质迁地保护技术体系, 实现 5,282 种药用植物迁地保护, 其中国家珍稀濒危保护物种 243种(内部资料)。

在动物和微生物遗传资源保护方面, 我国建成
了家养动物的1个国家级家畜基因库(北京)、1个国 家家养动物种质资源库(北京)、2个国家级地方鸡种 基因库(江苏和浙江), 2 个国家级水禽基因库(江苏 和福建)和 1 个国家级蜜蜂基因库(吉林)。截至2020 年底, 国家级家畜基因库和国家家养动物种质资源 库以冷冻精液、胚胎、体细胞等方式累计有效保存 家畜品种 300 个, 遗传物质达到 92 万份; 国家级地 方鸡种基因库和国家级水禽基因库以异地活体保 种方式有效保存禽类品种 85 个; 国家级蜜蜂基因库 采用蜜蜂活体保种和精液冷冻保存相结合的形式, 保存了 19 个蜜蜂品种(系), 约2万份蜜蜂样本。在水 产种质资源保护方面，建成31个遗传育种中心、84 家国家级水产原良种场、820家地方级水产原良种 场和35家遗传资源保存分中心, 形成了水生生物非 原生境保护的体系架构。农业微生物资源的保护相 对比较分散, 9 个国家级菌种保藏中心库藏资源总 量达221,720株, 备份320余万份(内部资料), 但每个 保藏中心中农业微生物的数量没有分开统计。

\subsection{2 原生境保护}

原生境保护有自然保护区、原种场、保种场和 原生境保护点几种方式。单纯为避免物种灭绝而建 设的国家级自然保护区主要是针对水生物种的保 护。据农业部国家级水产种质资源保护区公告 (http://www.moa.gov.cn), 截至2018年底, 已在全国 29 个省(自治区、直辖市)的濒危水生物种的产卵场、 索饵场、越冬场、洄游通道等区域建成535处国家 级水产种质资源保护区, 保护物种400多种, 一批 濒危物种如中华鳖(Trionyx sinensis)、湖北圆吻鲇 (Distoechodon tumirostris)、胭脂鱼 (Myxocyprinus asiaticus)、白甲鱼(Onychostoma sima)等得到了有效 保护, 维护了生物多样性和生态系统平衡。家养动 物的原生境保护是通过在原产地建立保种场和保 护区的方式进行活体保存, 近20年先后建立了 165 个国家级畜禽资源保护场和 24 个国家级畜禽遗传 资源保护区，65个种公畜站、1,209个原良种场, 覆 盖了全国30个省、直辖市和自治区(内部资料), 已基 本形成了以保种场和原种场为核心的保种体系。

作物遗传资源原生境保护主要有地方品种的 农民参与式保护和农业野生植物原生境保护点建 设两个方面。针对云南少数民族众多、农家保护的 作物地方品种及其相关传统知识极其丰富的现状, 国际植物遗传资源研究所与云南省农业科学院合 
作, 先后研究了云南陆稻地方品种、农民大田种植 作物、农民庭院及周围种植的观赏、园艺等作物地 方品种的多样性, 以及农民保护地方品种及其传统 知识的经验和做法, 提出了开展农民参与式地方品 种保护与可持续利用的建议(伍少云等, 2000, 2001, 2004，2005)。在农业野生植物原生境保护方面, 至 2018年底, 共建设原生境保护点205个。保护物种主 要包括粮油类作物野生近缘植物及具有重要开发 利用价值的野生蔬菜、果树、花卉、茶树、药用植 物等39种, 如野生大豆、野生稻、小麦野生近缘植 物 (Agropyron cristatum) 、野生柑橘 (Citrus reticulata)、野生茶、野生猕猴桃(Actinidia chinensis) 等, 分布于除北京、上海、西藏和港澳台外的 28 个 省(自治区、直辖市) (郑晓明等, 2019)。同时, 农业 农村部与联合国开发计划署(UNDP)合作执行了全 球环境基金(GEF) “中国作物野生近缘植物保护与 可持续利用”项目，设计了“以消除主要威胁因素为 导向的激励机制”的项目实施策略，成功地保护了 野生稻、野生大豆和小麦野生近缘植物的 8 个重要 居群, 并推广应用于15省的64个作物野生近缘植物 居群(郑晓明等, 2019)。

\subsection{3 以利用促保护}

野生动植物的驯养驯化在一定程度上保护了 农业生物物种。有些珍稀野生植物已开始作为绿化 植物引进栽培, 有些具有药用或观赏价值的野生植 物经过改进栽培措施已获得成功。据估计, 目前已 驯化栽培的野生植物达 1,000 种以上。对扬子鳄 (Alligator sinensis)和白暨豚(Lipotes vexillifer)等的 人工繁殖研究都取得了较大进展, 利用长江故道封 闭水域引入或放养“四大家鱼” “长江三鲟”等水生 动物, 达到保存水生物种的目的。

近年来，通过农业生物多样性的有效利用以促 进保护工作在多方面取得显著成绩，最典型的案例 是在利用品种多样性减轻病虫害的同时, 保护农业 生态系统和作物地方品种。例如, 朱有勇研究团队 针对我国西南地区气象特点和生物灾害频发的实 际情况, 深入研究并利用不同水稻品种(地方品种 和杂交品种)的混合间栽模式来控制稻瘟病的实践 表明, 生物多样性的合理布局不仅解决了作物病害 的控制问题, 同时还提高了水稻单位面积的产量, 大大减少了农药和化肥的使用量, 改善了农业生态 环境, 为现代农业生态环境下如何实现可持续生产
展示了光明的前景(杜雯翠和江河, 2017)。其中，一 些在云南省已经消失和趋于濒危的水稻地方品种, 如“弥勒香谷”和“黄板锁”等又逐渐回归到地方农业 生态系统。以生物多样性布局为基础的不同农作物 品种的混合间栽模式可能成为水稻地方品种，甚至 是其他农作物地方品种农家保护的新方法, 既起到 了地方品种保护的作用，同时又兼顾了农民的经济 利益。同时, 朱有勇研究团队还拓展利用物种合理 配置促进营养利用, 增加生物固氮, 增强作物抗逆 性; 集成物种多样性时空优化配置要素, 构建控制 病虫害促进增产的技术体系。2007-2010年在西南 地区累计推广 8,500 多万亩，并被云南省人民政府 列为科技增粮重大推广技术措施(王一等，2015; 王 金南等, 2018), 形成了作物多样性时空配置有效控 制病害技术创新体系，客观上也保护了众多农业物 种和作物品种的多样性。

\section{3 中国农业生物多样性保护存在的主要问题}

\section{1 未与国际国内发展战略相衔接}

自1993年《生物多样性公约》生效以来, 全球 生物多样性保护已从生态系统、物种和遗传多样性 3个层面开展具体保护行动逐步转变为保护与利用 并举、以利用促保护的过渡阶段，强调以生态系统 方法将生物多样性保护与生产生活、人类健康、环 境保护和气候变化等综合考量。2010年，《生物多 样性公约》第10次缔约方大会通过的《2011-2020 年生物多样性目标》确定了 5 个战略目标 (https://www.cbd.int), 除继续强调加大保护和可持 续利用的力度外，还提出了将生物多样性纳入整个 政府和社会的主流、增进生物多样性和生态系统服 务、通过参与式计划、知识管理和能力建设增强公 众保护意识等战略目标。《中国生物多样性保护战 略与行动计划》(环境保护部等, 2011)明确了我国生 物多样性保护“以实现保护和可持续利用生物多样 性、公平合理分享利用遗传资源产生的惠益为目标, 加强生物多样性保护体制和机制建设, 强化生态系 统、生物物种和遗传资源保护能力，提高公众保护 与参与意识, 推动生态文明建设, 促进人和自然和 谐”的指导思想，并提出了 8 项战略任务和 10 个优先 领域。因此, 无论从国际还是国内来看, 发挥生态 系统服务功能、生物多样性的主流化以及保护能力 建设都是目前国际国内生物多样性发展战略的重 
要组成部分。生态系统服务功能是指生态系统与生 态过程所形成及所维持的人类赖以生存的自然环 境与效用, 包括供给功能、调节功能、文化功能以 及支持功能(欧阳志云和王如松, 2000)。生物多样性 主流化在国际上已被认为是最有效的生物多样性 保护与可持续利用措施之一。通过生物多样性的主 流化, 将生物多样性纳入到经济、社会发展的主流, 促进全民参与生物多样性保护, 从而避免先破坏后 保护, 做到防患于未然, 使生物多样性保护与经济 发展得以同步进行(张风春等, 2015)。

目前我国的农业生物多样性保护仍然停留在 通过项目、工程等方式进行各项保护活动的层面。 中央各部门以及各级政府在强化土壤污染管控和 修复、加强农业面源污染防治、开展农村人居环境 整治行动、实施重要生态系统保护和修复重大工 程、优化生态安全屏障体系、构建生态廊道和生物 多样性保护网络、严格保护耕地、扩大轮作休耕试 点、健全耕地草原森林河流湖泊休养生息制度、建 立多元化生态补偿机制等方面, 实施了一系列与农 业生物多样性保护相关的工作。然而, 上述工作尚 未形成相应的体系、机制或制度, 也未能按照《生 物多样性公约》和《中国生物多样性保护战略与行 动计划》制定的重大战略目标进行规范化、系统化 的保护, 未与国际国内发展战略相衔接。2018年农 业部更名为农业农村部后, 突破了农业生物多样性 以农业生态系统为主的局限, 将农业生物多样性提 升到以乡村为主体的农业景观层面, 在更加系统地 开展保护的同时, 注重发挥生态系统服务功能并实 现其在基层政府和农民中的主流化。但这些工作才 刚刚起步, 与国际国内发展战略的需求还相距 甚远。

\section{2 国内保护体系尚不完整}

到目前为止, 我国既无农业生物多样性专门管 理机构, 又无相应的研究机构, 也缺乏专门针对农 业生物多样性的法律法规。从行政职能看, 在生态 系统和物种多样性层面与自然资源部(国家林业和 草原局)、生态环境部、水利部等部门交叉重叠; 在 遗传多样性层面, 农业农村部内部又由种植业、畜 牧业、渔业、种业、科技教育等多个司局分别管理, 农业生物多样性管理仍然是各部门、各单位各自为 政。在保护的具体行动上, 一是主要以部门规划、 项目、工程等方式分别实施, 彼此之间缺乏有效沟
通和有机联系; 二是将生态系统、物种和遗传多样 性3个层次割裂, 并且大多数已开展活动的对象是 农业生物多样性, 但并不以农业生物多样性的概念 出现, 导致除实施单位外的各利益相关方特别是地 方政府和农民长期缺乏对生物多样性保护的了解; 三是科研力量分散, 目前在国家学科分类体系中尚 无农业生物多样性学科或分支学科, 科研单位和高 等院校也无相应专业, 从事有关工作的科研人员只 能作为 “兼职”而非专职的农业生物多样性工作者。

\section{3 国内保护能力不足}

农业生物多样性保护是一项战略性、长期性、 公益性的工作。首先需要政府稳定的财政支持, 其 次是应建立一支稳定的研究队伍，第三是应制定一 套对农业生物多样性保护工作者合理的评价机制, 第四是需要构建农业生物多样性保护的激励机制, 第五是营造一个全民重视农业生物多样性保护的 良好氛围。目前我国在农业生物多样性保护方面恰 恰缺乏这方面的相关政策和行动。例如, 目前我国 农业生物多样性保护设施设备的运行、保护行动等 基础性工作经费仍然需要科研人员去争取项目; 农 业生物多样性保护工作因发表高水平论文难度大, 职称晋升、成果奖励、考核考评等在现有评价体系 下都无法与其他科研人员竞争, 保护工作者的贡献 无法体现, 大量科研人员没有真正从事农业生物多 样性保护工作; 农业生物多样性保护与经济发展一 旦发生冲突, 无论是政府、企业还是普通居民往往 以经济发展为目标, 以牺牲农业生物多样性为代价 等, 这是目前农业生物多样性保护的主要障碍。

\section{4 对我国农业生物多样性未来工作重点的建}

\section{1 加大农业生物多样性的国际履约力度}

目前我国农业生物多样性保护未与国际国内 发展战略相衔接的主要原因之一是推动国际履约 的力度不够。在履行《生物多样性公约》及《生物 多样性公约关于遗传资源获取与惠益分享的名古 屋议定书》(简称《名古屋议定书》) 方面, 虽然在开 展的农业生物多样性保护和可持续利用活动中有 一些与爱知生物多样性目标一致, 但并未将爱知生 物多样性目标纳入农业农村部的发展战略, 特别是 在生物多样性主流化、能力建设和遗传资源获取与 惠益分享等方面差别较大。在履行与农业生物多样 性密切相关的《粮食和农业植物遗传资源国际条 
约》(简称《条约》) 方面, 虽然一直参与《条约》的 谈判, 并在国内实际工作中努力与 《条约》中的一 些规定相适应，但至今未作为缔约方加入《条约》。

建议我国加大农业生物多样性的国际履约力 度。首先应尽快推动加入《条约》, 并系统梳理《生 物多样性公约》 《名古屋议定书》和《条约》中有 关农业生物多样性保护的条款, 开展我国履约现状 与空缺分析, 根据国际发展动态, 制定履约策略, 逐步将农业生物多样性保护与国际接轨, 将爱知生 物多样性目标等国际生物多样性发展目标纳入农 业农村部的规划和计划, 及时更新《中国农业部门 生物多样性保护行动计划》(农业部生物多样性保护 行动计划专家组, 1993), 全面系统地加大农业生物 多样性国际履约力度。

\section{2 完善农业生物多样性保护体系}

农业生态系统保护的重点在于农田与种植系 统、畜牧与草地系统、湿地与农区及其他野生生态 系统、自然保护区内及周边农业生态系统、内陆及 海洋渔业系统等几个方面(章家恩和饶卫民, 2004)。 目前这些系统的保护已受到社会各界的重视, 特别 是农业农村部已采取大量措施改善各生态系统条 件, 但一旦保护与利用发生冲突, 则往往注重的是 利益优先。因此, 必须建立农业生态系统从中央到 地方的长期保护机制, 把农业生态系统的良性发展 作为优先目标, 以达到持续保护的目的。在物种和 遗传资源保护方面, 要建立调查收集、异位保存、 原生境保护、监测预警和创新利用相结合的保护网 络, 解决以往保护利用各组成部分相互脱节的矛 盾。更为重要的是，应根据2020年国务院印发的《关 于加强农业种质资源保护与利用的意见》要求, 加 强动植物种质资源保护利用, 在推进种质资源收集 保存、鉴定和育种的同时, 组织开展农业种质资源 登记, 实行统一身份信息管理, 制定遗传资源获取 与惠益分享制度, 健全国家农业种质资源保护与利 用体系。

\section{3 促进农业生态系统服务功能的系统化}

在生态系统服务功能上, 目前更多地是关注其 产品服务功能及其价值, 而忽视其环境服务价值、 旅游服务价值和文化美学价值等(章家恩和饶卫民, 2004)。未来应注重将农业生态系统上升到农业景观 层面, 特别是职能调整后的农业农村部应统一规划 农业和农村的协调发展, 在继续加强现有各项生态
系统保护措施的同时, 充分发挥农业生态系统的生 产、生态、生活功能(“三生”功能)。一是利用生态 系统方法促进生产，如近年来大力发展的稻一鱼 (虾、蟹)共养、林下种植、林下养殖、“三品一标” (无 公害产品、有机产品、绿色产品、地理标志产品) 等生产方式，既能保护生态系统中的生物多样性， 又能节约成本和增加收入; 二是通过调整种养结 构、改良栽培措施、提高农业废弃物利用效率等措 施，减少污染物及温室气体(如 $\left.\mathrm{CO}_{2} 、 \mathrm{CH}_{4}\right)$ 的排放等, 发挥生态和环境功能; 三是大力发展休闲农业、观 光农业和开发农业文化遗产的文化价值，实现农业 生态系统的生活功能。

\section{4 加快农业生物多样性主流化进程}

我国农业生物多样性保护目前还停留在农业 行政主管部门及其事业单位工作人员，以及农业科 研单位和农业院校的研究人员层面，非农业领域的 官员、专家特别是广大民众严重缺乏农业生物多样 性保护意识, 我国农业生物多样性主流化任重而道 远。因此, 最为重要的是农业生物多样性在从中央 到地方各级、各部门政府官员中的主流化，将农业 生物多样性保护纳入各级、各部门制定的各类政 策、规划、计划之中。例如, 水电站或水利设施建 设时，应充分考虑其对鱼类资源及其产卵场、洄游 地的影响。第二，基层工作人员和农村居民是农业 生物多样性保护的主要力量, 只有他们认识到农业 生物多样性保护的重要性并主动参与到保护行动 中, 保护活动才能顺利开展, 保护工作才可持续。

第三，各类宣传媒体是农业生物多样性主流化的核 心力量, 肩负着提高全民保护农业生物多样性意识 的重任, 要充分发挥媒体传播的重大作用, 组织各 类媒体广泛开展农业生物多样性的重要性、保护的 必要性和紧迫性以及可持续利用的远大前景宣传, 让农业生物多样性保护的理念深入人心, 实现农业 生物多样性保护在广大民众中的主流化。

\section{5 加强农业生物多样性保护的能力建设}

农业生物多样性保护工作属于基础性、长期 性、公益性工作，应将农业生物多样性保护基础性 工作经费列入中央财政预算，对于农业生物多样性 保护体系的运行等予以长期稳定的中央财政经费 支持。同时，鼓励科研机构、公益性组织以及国际 农业研究机构等参与农业生物多样性保护。组建一 支由公益性机构组成的农业生物多样性保护专业 
人才队伍, 并从人才培养、考核评价、职称晋升、 待遇保障等方面建立起一整套人才管理与激励的 机制, 以稳定人才队伍, 充分调动农业生物多样性 保护工作者的积极性和创造性。

探索多种方式相结合的农业生物多样性保护 的公众参与模式。加强农业生物多样性科学教育, 在基础教育和高等教育中传授农业生物多样性科 学知识; 制定新形势下的农业生物多样性科学普及 策略, 传统媒体与网络新媒体相结合, 加强农业生 物多样性科普宣传; 与乡村振兴战略相结合, 加强 农业生物多样性的主流化, 在庭院保护、特色小镇 与观光农业发展中融入农业生物多样性保护的理 念等, 建立和完善公众参与农业生物多样性保护与 利用的有效机制。

\section{参考文献}

Ding LB, He SY, Min QW (2019) Evaluation and conservation of agricultural biodiversity in agricultural heritage systems. Study on Natural and Cultural Heritage, 4(11), 44-47. (in Chinese with English abstract) [丁陆涁, 何思源, 闵庆文 (2019) 农业文化遗产系统农业生物多样性评价与保护. 自然与文化遗产研究, 4(11), 44-47.]

Dong YC, Cao YS (2003) Quality characteristics of germplasm resources of food crops and their utilization. Scientia Agricultura Sinica, 36, 111-114. (in Chinese) [董玉琛, 曹 永生 (2003) 粮食作物种质资源的品质特性及其利用. 中国农业科学, 36, 111-114.]

Du WC, Jiang H (2017) Five innovations in the prevention and control of pollution source in the 13th five-year plan period. Environmental Protection, 45(15), 50-53. (in Chinese) [杜 雯翠, 江河 (2017) 从 《“十三五”生态环境保护规划》看 源头防控的五个创新. 环境保护, 45(15), 50-53.]

Expert Group on the Biodiversity Conservation Action Plan of the Ministry of Agriculture (1993) Action Plan for Biodiversity Conservation of the Chinese Agricultural Department. China Agriculture Press, Beijing. (in Chinese) [农业部生物 多样性保护行动计划专家组 (1993) 中国农业部门生物 多样性保护行动计划. 中国农业出版社, 北京.]

FAO (2010) The Second Report on the State of World's Plant Genetic Resources for Food and Agriculture. FAO, Rome.

Guo HJ, Padoch C, Fu YN, Chen AG, Dao ZL (2000) agrobiodiversity assessment and in-situ conservation. Acta Botanica Yunnanica, 22(Suppl. XII), 27-41. (in Chinese with English abstract) [郭辉军, Christine Padoch, 付永能, 陈爱国, 刀志灵 (2000) 农业生物多样性评价与就地保 护. 云南植物研究, 22(Suppl. XII), 27-41.]

Huang H, Fu ZQ, Liu XY, Chen C, Huang XG, Wang H, Dai ZY, Yu ZJ, Liao XL, Zhang Y, Zheng HB, Long P, Xu Y (2019) On farmland ecological planting and breeding project. Crop Research, 33, 339-345. (in Chinese with English abstract) [黄璜, 傅志强, 刘小燕, 陈灿, 黄兴国, 王华, 戴振炎, 余政军, 廖晓兰, 张亚, 郑华斌, 龙攀, 徐 莹 (2019) 论农田生态种养工程。作物研究, 33, 339-345.]

He JJ, Liu GQ (2016) Annual working conference on the protection and utilization of crop germplasm resources was held. Journal of Plant Genetic Resources, 17, 577. (in Chinese) [何娟娟, 刘根泉 (2016) 农作物种质资源保护 与利用专项2016年度工作会议召开. 植物遗传资源学报, 17, 577.]

Jiang QW, Liu F, Peng YX, Wang H, Yao R, Li HF, Luo P, Liu XL, Wu JS (2019) Nitrogen and phosphorus removal by integrated ecological engineering treatment system in a small agricultural watershed. Environmental Science, 40, 2194-2201. (in Chinese with English abstract) [蒋倩文, 刘 锋, 彭英湘, 王华, 姚燃, 李红芳, 罗沛, 刘新亮, 吴金水 (2019) 生态工程综合治理系统对农业小流域氮磷污染的 治理效应. 环境科学, 40, 2194-2201.]

Li B (1999) Conservation and sustainable utilization of biodiversity in Chinese agricultural regions. Journal of Agro-environment and Development, 16(4), 9-15. (in Chinese) [李波 (1999) 中国的农业生物多样性保护及持 续利用. 农业环境与发展, 16(4), 9-15.]

Li DZ, Lou ZP (2006) Implementing international conventions to build a germplasm resource bank of southwestern China. Bulletin of the Chinese Academy of Sciences, 21, 79-87. (in Chinese) [李德铢, 娄治平 (2006) 履行国际公约建设中 国西南野生生物种质资源库. 中国科学院院刊, 21, 79-81.]

Liao JJ, Huang H, Li WW, Wang L, An LN (2019) A new perspective on marine biological diversity of areas beyond national jurisdiction (BBNJ): Making use of area-based management tools (ABMTs), including marine protected areas (MPAs). Biodiversity Science, 27, 1153-1161. (in Chinese with English abstract) [廖建基, 黄浩, 李伟文, 王 否, 安丽娜 (2019) 国家管辖范围以外区域海洋生物多 样性保护的新视域:包括海洋保护区在内的划区管理工 具. 生物多样性, 27, 1153-1161.]

Liu X, Zheng DS, Dong YC, Zhu DW, Fang JH, Fei YL, Jia JX, Jiang YQ, Yang QW, Wang SM, Li Y, Cao YS (2008) Diversity assessment of crops and their wild relatives in China. Journal of Plant Genetic Resources, 9, 411-416, 408. (in Chinese with English abstract) [刘旭, 郑殿升, 董玉琛, 朱德蔚, 方嘉禾, 费砚良, 贾敬贤, 蒋尤泉, 杨庆文, 王 述民, 黎裕, 曹永生 (2008) 中国农作物及其野生近缘植 物多样性研究进展. 植物遗传资源学报, 9, 411-416, 408.]

Long CL, Li H, Ouyang ZQ, Yang XY, Li Q, Trangmar B (2003) Strategies for agrobiodiversity conservation and promotion: A case from Yunnan, China. Biodiversity \& Conservation, 12, 1145-1156.

Lu XX, Xin X, Yin GK, Zhang JM, Chen XL, Wang SM, Fang W, He JJ (2019) Theory and practice of the safe 
conservation of crop germplasm resources in China. Journal of Plant Genetic Resources, 20, 1-10. (in Chinese with English abstract) [卢新雄, 辛霞, 尹广婫, 张金梅, 陈晓 玲, 王述民, 方沩, 何娟娟 (2019) 中国作物种质资源安 全保存理论与实践. 植物遗传资源学报, 20, 1-10.]

Ministry of Environmental Protection (2011) China Biodiversity Conservation Strategy and Action Plan. China Environmental Science Press, Beijing. (in Chinese) [环境保 护部 (2011) 中国生物多样性保护战略与行动计划. 中 国环境科学出版社, 北京.]

Min QW, Zhao LJ, Ye ME (2007) The Rome conference on the protection of agricultural cultural heritage and its main achievements. Geographical Research, 22, 211-212. (in Chinese) [闵庆文, 赵立军, 叶明儿 (2007) 农业文化遗产 保护的罗马会议及其主要成果. 地理研究, 22, 211-212.]

Ouyang ZY Wang RS (2000) Ecosystem services and their economic valuation. World Science and Technology Research and Development 22(5), 45-50. (in Chinese with English abstract) [欧阳志云, 王如松 (2000) 生态系统服 务功能、生态价值与可持续发展. 世界科技研究与发展, 22(5), 45-50.]

Peng CL, Qi CJ, Yan LH, Liao JY, Feng GX, Lai XL (2020) A comprehensive review on the relationship between biodiversity and ecosystem services. World Forestry Research, 33(2), 1-12. (in Chinese with English abstract) [彭春良, 祁承经, 颜立红, 廖菊阳, 冯贵祥, 赖小连 (2020) 生物多样性与生态系统服务关系综评. 世界林业 研究, 33(2), 1-12.]

Shi RF (2013) Thoughts on biodiversity conservation and its legal building. State Academy of Forestry Administration Journal, 12(4), 36-39, 56. (in Chinese with English abstract) [史瑞芳 (2013) 关于生物多样性保护及其法制建设的思 考. 国家林业局管理干部学院学报, 12(4), 36-39, 56.]

Shi XY, Guo R (2011) Biodiversity conservation and ecological risk prevention legal construction. In: Proceedings of the 2011 Annual Meeting of the Society of Environmental Resources Law of the China Law Society, pp. 1-7, Guilin. (in Chinese) [史学瀛, 郭融 (2011) 生物多样性保护与生 态风险防范法制建设. 见: 中国法学会环境资源法学研 究会2011年年会论文集, 1-7页, 桂林.]

Wang JN, Wan J, Wang Q, Su JQ, Yang LY, Xiao Y (2018) The development of China's ecological and environmental planning in forty years of reform and opening-up. Chinese Journal of Environmental Management, 10(6), 5-18. (in Chinese with English abstract) [王金南, 万军, 王倩, 苏洁 琼, 杨丽阎, 肖旸 (2018) 改革开放40年与中国生态环境 规划发展. 中国环境管理, 10(6), 5-18.]

Wang KL, Zhou YH, Huang ZA, Zhu LJ, Xu J (2017) Effects of paddy-upland rotation on the characteristics of soils and crop yields. Vegetables, (5), 21-23. (in Chinese with English abstract) [王克磊, 周友和, 黄宗安, 朱隆静, 徐坚 (2017) 水旱轮作对土壤性状及作物产量的影响. 蔬菜, (5), 21-23.]
Wang Y, Yang YT, Yang J, Liu L, Zhu YY, Li CY (2015) Current state of species diversity and pest management. Chinese Journal of Biological Control, 31, 801-810. (in Chinese with English abstract) [王一, 杨雅婷, 杨静, 刘林, 朱有勇, 李成云 (2015) 物种多样性与病虫草害管理研 究进展. 中国生物防治学报, 31, 801-810.]

Wen DZ (1995) A primary discussion on agroecosystem diversity. Chinese Journal of Applied Ecology, 6, 97-103. (in Chinese with English Abstract) [闻大中 (1995) 试论农 业生态系统的多样性. 应用生态学报, 6, 97-103.]

Wen Z, Zheng H, Ouyang ZY (2020) Research progress on the relationship between biodiversity and ecosystem services. Chinese Journal of Applied Ecology, 31, 340-348. (in Chinese with English abstract) [文志, 郑华, 欧阳志云 (2020) 生物多样性与生态系统服务关系研究进展. 应用 生态学报, 31, 340-348.]

Wu SY, Dai LY, You CL, Jin JC, Li Y, Jia CJ, Zhang ZW, Sthapit BR (2001) Analysis of relationship between crops diversity at household level and household income. Acta Botanica Yunnanica, 23(Suppl. XIII), 187-193. (in Chinese with English abstract) [伍少云, 戴陆园, 游承俐, 金建昌, 李云, 贾从进, 张宗文, Bhuwon R. Sthapit (2001) 户级水 平大田作物多样性与经济关系分析. 云南植物研究, 23(Suppl. XIII), 187-193.]

Wu SY, Dai LY, You CL, Li Y, Zhang ZW, Rhapit B (2005) Conservation and utilization of plant resources diversity at the household level in Shuangqiao Village, Kunming, Yunnan Province. Journal of Plant Genetic Resources, 6, 431-436. (in Chinese with English abstract) [伍少云, 戴陆 园, 游承俐, 李云, 张宗文, Bhuwon Rhapit (2005) 云南 昆明市双哨乡双桥村户级植物资源多样性保护与利用. 植物遗传资源学报, 6, 431-436.]

Wu SY, You CL, Dai LY, Jin JC, Zhang ZW, Quek P, Yang JS (2000) Diversity of upland rice germplasm resources and in situ conservation in Lancang County, Yunnan Province. Journal of Plant Resources and Environment, 9(4), 39-43. (in Chinese with English abstract) [伍少云, 游承俐, 戴陆 园, 金建昌, 张宗文, Paul Quek, 杨家寿 (2000) 云南澜 沧县陆稻品种资源多样性和原生境保护. 植物资源与环 境学报, 9(4), 39-43.]

Wu SY, Zhang ZW, Sthapit BR, You CL, Li Y, Dai LY (2004) Curtilage plant diversity at the household level in Shuangqiao Village. Rural Eco-Environment, 20(1), 16-19. (in Chinese with English abstract) [伍少云, 张宗文, Bhuwon R. Sthapit, 游承俐, 李云, 戴陆园 (2004) 昆明 市双哨乡户级庭园植物多样性分析. 农村生态环境, 20(1), 16-19.]

Xie LF, Liu QS, Han WJ, Guo ZY (2018) Application and analysis of combined agricultural, biogas, and quantitative application cycle agriculture in North China Plain. Agricultural Science and Technology Newsletter, (8), 248-250, 293. (in Chinese) [谢利芬, 刘庆生, 韩文君, 郭 智勇 (2018) 华北平原区种养沼结合、定量施用循环农业 
应用及分析. 农业科技通讯, (8), 248-250, 293.]

$\mathrm{Xu} \mathrm{XJ,} \mathrm{Zhao} \mathrm{J,} \mathrm{Zhang} \mathrm{WL,} \mathrm{Zhang} \mathrm{YC,} \mathrm{Yao} \mathrm{Z} \mathrm{(2016)}$ Potassium nutrient balance and its impact on soil available K content in Shanghai suburb farmlands. Soil and Fertilizer Sciences in China, (3), 37-42. (in Chinese with English abstract) [许仙菊, 赵坚, 张维理, 张永春, 姚政 (2016) 不同轮作模式农田钾养分表观平衡及其对土壤速效钾含 量的影响. 中国土壤与肥料, (3), 37-42.]

Xue DY, Zhang YY (2019) Achievement and outlook of biodiversity conservation in China. Environmental Protection, 47(17), 38-42. (in Chinese) [薛达元, 张渊媛 (2019) 中国生物多样性保护成效与展望. 环境保护, 47(17), 38-42.]

Yang QW, Yu LQ, Zhang WX, Chen DZ, Shi JX, Ren JF, Miao H (2005) Comparative studies on genetic diversities between in-situ and ex-situ conserved germplasm of Oryza rufipogon. Scientia Agricultura Sinica, 38, 1073 -1079. (in Chinese with English abstract) [杨庆文, 余丽琴, 张万霞, 陈大洲, 时津霞, 任军方, 苗晗 (2005) 原、异位保存普 通野生稻种质资源的遗传多样性比较研究. 中国农业科 学, 38, 1073-1079.]

Yang QW, Zhang WX, He DX, Chen DZ, Dai LY, Chen CB, Huang KD (2003) Study on in-situ conservation methods of wild rice in China. Journal of Plant Genetic Resources, 4, 63-67. (in Chinese with English abstract) [杨庆文, 张万霞, 贺丹霞, 陈大洲, 戴陆元, 陈成斌, 黄坤德 (2003) 中国 野生稻原生境保护方法研究. 植物遗传资源学报, 4, 63-67.]

Yang R, Peng QY, Cao Y, Zhong L, Hou SY, Zhao ZC, Huang C (2019) Transformative changes and paths toward biodiversity conservation in China. Biodiversity Science, 27, 1032-1040. (in Chinese with English abstract) [杨锐, 彭钦 一, 曹越, 钟乐, 侯姝或, 赵智聪, 黄澄 (2019) 中国生 物多样性保护的变革性转变及路径. 生物多样性, 27, 1032-1040.]

Zhang D, Min QW, He L, Yuan Z (2016) Agrobiodiversity features, conservation and utilization of China's Globally Important Agricultural Heritage Systems. Chinese Journal of Eco-Agriculture, 24, 451-459. (in Chinese with English abstract) [张丹, 闵庆文, 何露, 袁正 (2016) 全球重要农 业文化遗产地的农业生物多样性特征及其保护与利用. 中国生态农业学报, 24, 451-459. ]

Zhang FC, Liu WH, Li JS (2015) Current situation and countermeasures of biodiversity mainstreaming in China. Environment and Sustainable Development, 40(2), 13-18. (in Chinese with English abstract) [张风春, 刘文慧, 李俊
生 (2015) 中国生物多样性主流化现状与对策. 环境与 可持续发展, 40(2), 13-18.]

Zhang JE (1999) Agricultural biodiversity in China and its protection. Rural Eco-Environment, 15(2), 37-41. (in Chinese with English abstract) [章家恩 (1999) 中国农业 生物多样性及其保护. 农村生态环境, 15(2), 37-41.]

Zhang JE, Rao WM (2004) Discussion on agroecosystem services and sustainable utilization. Chinese Journal of Ecology, 23(4), 99-102. (in Chinese) [章家恩, 饶卫民 (2004) 农业生态系统的服务功能与可持续利用对策探 讨. 生态学杂志, 23(4), 99-102.]

Zhang LC, Shao JH, Lin YQ, Kuang XL, Zhang HL, Qing C, Ma L, Yao BS (2017) Influence of microbial diversity and activity of soil on the rice-rice-rape rotation. Ecology and Environmental Sciences, 26, 204-210. (in Chinese with English abstract) [张立成, 邵继海, 林毅青, 匡晓琳, 张卉 灵, 卿纯, 马力, 姚帮松 (2017) 稻一稻-油菜轮作对土壤 微生物活性和多样性的影响. 生态环境学报, 26, 204-210.]

Zhang XY, Yang QW (2019) Option and recommendations for the China's accession to the International Treaty on Plant Genetic Resources for Food and Agriculture. Journal of Plant Genetic Resources, 20, 1110-1117. (in Chinese with English abstract) [张小勇, 杨庆文 (2019) 我国加入《粮食 和农业植物遗传资源国际条约》的选择和建议. 植物遗传 资源学报, 20, 1110-1117.]

Zheng DS, Hao SQ (1990) China's achievements in the inspection of crop genetic resources in the past decade. World Agriculture, (9), 26-28. (in Chinese) [郑殿升, 郝素 琴 (1990) 中国近十年的作物遗传资源考察的成就. 世 界农业, (9), 26-28. ]

Zheng XM, Chen BX, Song Y, Li F, Wang JR, Qiao WH, Zhang LF, Cheng YL, Sun YF, Yang QW (2019) In-situ conservation of wild relatives of crops. Journal of Plant Genetic Resources, 20(, 1103-1109. (in Chinese with English abstract) [郑晓明, 陈宝雄, 宋玥, 李飞, 王君瑞, 乔卫华, 张丽芳, 程云连, 孙玉芳, 杨庆文 (2019) 作物 野生近缘种的原生境保护. 植物遗传资源学报, 20, 1103-1109.]

Zhou JX (2018) Key technical specifications for the production of pollution-free agricultural products. Agricultural Engineering Technology, 38(8), 68-69. (in Chinese) [周建雄 (2018) 无公害农产品生产关键技术规范. 农业工程技术, 38(8), 68-69.]

(责任编委: 龙春林 责任编辑: 黄祥忠) 